\title{
Optimization of Self-Effication Based on the Christian Faith Community of SMA N 1 Amurang Students
}

\author{
Heldy J. Rogahang ${ }^{1}$,Wolter Weol $^{2}$ \\ Institut Agama Kristen Negeri Manado \\ heldyjrogahang@iakn-manado.ac.id ${ }^{1}$,wolterweol@iakn-manado@ac.id²
}

\begin{abstract}
The church is a Christian faith community whose duty is to educate, teach and train church members. Self-efficacy includes the confidence that an individual has in his or her abilities, and a person's evaluation of his or her ability and competence to perform a task to achieve certain results. Self-efficacy refers to a person's level of confidence or self-confidence in his abilities, which indirectly motivates himself to take the necessary actions to achieve a certain thing. Self-efficacy is also able to influence several aspects of one's cognition and behavior, given the different behavior of an individual with another. Training is an effective method for shaping character and optimizing the self-efficacy of students. The self-efficacy process in the school environment is formed through the school community which is named Pelsis (Student Service), and should be a means of holding various activities that explore the potentialof students. However, the development activities of students in the Pelsis community at SMAN 1 Amurang currently are only in the form of conventional worship or fellowship. The faith community which is the goal of religious education today includes three important things, namely normative ideals, reflection and support, as well as group discussions. Things like this will help students in developing their self-efficacy.
\end{abstract}

Keywords: Self-Efficacy, Christian Faith, Christian Education.

\section{Introduction}

The issue of student self-efficacy is one of the topics that is often discussed nowadays, not only among educational institutions in schools and educational foundations, but a conversation with the general public; in markets, malls and other communities. Interestingly, the conversation about the issue of student self-efficacy is due to the many problems encountered in society, where students ranging from elementary school to high school / vocational school in various places do, which on the one hand shows quite a lot of both academic and nonacademic achievements. This means that not a few students have the ability to explore their ability to excel, which certainly has a positive impact on the future of their studies. However, on the other hand, quite a lot of students at all levels of education actually show indifference, lack of enthusiasm, apathy, and other pessimistic facts of life. So it is not uncommon for them to experience dropping out of school, dropping out, which then has a negative impact on their association.

Based on these conditions, various efforts have certainly been made by the government, including: 12 Years Compulsory Education, the Education for All campaign accompanied by educational funds such as BOS, Education Cards, and others. Not only the government, profit organizations such as banks, companies / industries, and foundations engaged in education also actively and continuously promote education. Constitutional foundation; "The intellectual life of the nation" is the spirit of all educational movements in Indonesia. 
From a Christian perspective, education is the mandate of the Great teacher of Jesus Christ. Andar Ismail in his book "Teach Them Do" inspire and motivate the church and / or Christian community to educate, teach and train students properly and properly so that they become a blessing for many people in various places, from time to time. This idea has also been put forward by Robert Boelkhe; think theologically about pedagogical issues; pedagogical thinking about theological issues. A dialectic that demands the critical power of the church in terms of introducing and pursuing Christian education based on the Bible.

The church is a community of the Christian faith, of course, has an important task to educate, teach and train church members as learners. Educating with the heart, Teaching with faith, and Training with the body and soul are a very combinative approach so that the character of students who are tough, strong and not easily swayed. However, various facts of the service that the church as a community performs for students are not much different from what is done on Sundays, namely conventional "worship". The service approach to school-age students is philosophically different; different approaches, different materials, methods and strategies. There are programs that are very fundamental in the church to shape the character of students, namely: "bible camp", "retreat", and other programs. However, the effect of these activities is not significant, which shows the "spiritual formation" of students.

Likewise with the student faith community, which is known as Student Service (PELSIS). The Pelsis faith community is also formed in almost all levels of education from SD to SMA / SMK with Christian students. However, the practice of the service is also the same as what is done by the church, namely conventional or communal worship. Activities that explore selfpotential through trainings are rarely done. In biblical terms, training is an effective method for shaping character and optimizing the self-efficacy of students.

\section{Result and Discussion}

\subsection{Self-Efficacy Concept}

Bandura (1997: 2) defines self-efficacy as an individual's belief in his or her ability to perform tasks or actions needed to achieve certain results[1] Baron and Byrne (1991: 5), selfefficacy as a person's evaluation; Self Efficacy against Thinking Ability; regarding his ability or competence to perform a task, achieve goals, and overcome obstacles [2].

Based on this understanding, it can be understood that self-efficacy includes the confidence that individuals have in their abilities and one's evaluation of their abilities and competences to carry out a task to achieve certain results. The same thing is also expressed by Luthans (2006: 102) as below: "Self-efficacy refers to an individual's belief (or confidence) regarding his ability to mobilize motivation, cognitive resources, and actions needed to successfully carry out a task in a certain context[3]".

Based on the defined definition, it is concluded that self-efficacy refers to a person's level of confidence or confidence in his or her abilities, which will indirectly motivate himself to take the necessary actions to achieve a certain thing. A broader description is put forward by Bandura [4] and Luthans[5], as below: "Self-efficacy refers to the belief in an individual's ability to drive motivation, cognitive abilities, and actions needed to meet the demands of the situation. Self-efficacy is not related to the skills they have, but it is related to an individual's belief about things that can be done with the skills he has regardless of the size. Luthans says that self-efficacy can lead to different behaviors among individuals with the same abilities because self-efficacy affects choices, goals, problem solving, and persistence in doing 
business. A person with high self-efficacy believes that they are able to do something to change the events around them, while someone with low self-efficacy considers himself basically unable to do everything around him. In difficult situations, people with low selfefficacy tend to give up easily. Meanwhile, people with high self-efficacy will try harder to overcome the challenges that exist. It can be concluded that self-efficacy will affect several aspects of one's cognition and behavior, therefore the behavior of an individual will be different from other individuals. Based on the definitions that have been described, it can be understood that self-efficacy is one's belief in one's ability to what is being faced, namely convincing oneself to maximize certain achievements by motivating oneself, maximizing their cognitive resources, and the actions needed to deal with them. Certain obstacles or achievements. People who have high self-efficacy tend to have a positive paradigm of their own abilities and are able to do something to change the situation around them, on the other hand, people who have low self-efficacy tend to think of themselves as unable to complete things and give up easily and have a negative paradigm of their abilities[7].

According to Luthan self-efficacy can be understood and information obtained through four (4) main sources of information, namely [8]:

a) Experience of success (Mastery Experience) Success experiences have a big influence on individual self-efficacy because they are based on individual personal experiences.

b) Experience of others (Vicarious Experience) Observation of the success of others with comparable abilities in doing a task will increase the self-efficacy of individuals in doing the same task. Vice versa, observing the failures of others will reduce an individual's assessment of his abilities and the individual will reduce the effort made.

c) Verbal Persuasion (Verbal Persuasion) In verbal persuasion, individuals are directed with suggestions, advice, and guidance so that they can increase their belief about the abilities they have that can help achieve the desired goals. Individuals who are reassured verbally tend to try harder to achieve success. The influence of verbal persuasion is not too large because it does not provide an experience that can be directly experienced or observed by the individual.

d) Physiological State (Physiological State). Individuals will find information on their physiological condition to assess their abilities. Physical tension in stressful situations is seen by individuals as a sign of incompetence because it can weaken individual work performance.

Based on the description of the sources of self-efficacy information disclosed by Luthans [9], it can be understood that the self-efficacy of each individual can be understood through four (4) sources, namely:

a) Mastery Experience, where one's source of information can be understood. Through the experience of success and failure of an individual. This means that individual experiences will greatly affect their own efficacy.

b) The experience of others (Vicarious Experience), which almost has the same meaning as the Mastery Experience, however, in this case, the source of information on one's selfefficacy is obtained through the experiences of success or failure of others who may have the same level of difficulty as the one being faced, so that indirectly it can also affect the self-efficacy of these individuals.

c) Verbal Persuasion, where a person's self-efficacy can increase or vice versa based on support or external factors, such as motivation, advice, advice, and guidance that the individual gets.

d) Physiological conditions (Physiological State), where the efficacy of a person is also influenced by factors of individual physiological conditions. A good physiological 
condition will increase the self-efficacy of the individual, on the other hand, a bad physiological condition will decrease the self-efficacy.

According to Luthans self-efficacy in each individual will differ from one individual to another based on three dimensions [10]. The following are the three dimensions:

1) Dimension Level / Magnitude (Magnitude). This dimension relates to the degree of difficulty of the task when the individual feels capable of doing it. If an individual is faced with tasks arranged according to their level of difficulty, then the individual's selfefficacy may be limited to easy, moderate, or even the most difficult tasks, in accordance with the perceived ability limits to meet the behavioral demands required in each level. Individuals will try to behave beyond their perceived ability.

2) Dimensions of Area (Generalilty) This dimension is related to the area of behavior in which individuals feel confident in their abilities. Individuals can feel confident in their abilities, whether it's limited to a certain activity or to a series of activities and various situations.

3) Dimension of Strength (Strength). This dimension relates to the strength level of an individual's belief or expectation regarding his ability. Weak expectations are easily swayed by unsupportive experiences. On the other hand, steady experiences encourage the individual to stay in his business. This dimension is usually directly related to the level dimension, that is, the higher the difficulty level of the task, the weaker the confidence that is felt to complete it.

\subsection{Faith Community}

The very well-known concept of the Christian Community of Faith described by Jack L. Seymour. Faith communities that are the goals of religious education are:

1. The normative ideal. Education that can link individual and group development together

2. Reflection and support. Sharing life-sizing among small group members based on the scriptures

3. Discussion. Discussions about life experiences to strengthen personal and group building.

\section{Refrences}

[1] Bandura, A., Self-Efficacy, The Exercise of Control. W.H. Freeman and Company, New York, p. 2 (1997)

[2] Baron \& Byrne, Social Psychology. sixth edition: Understanding human interaction. United States of America: Allyn and Bacon, p. 5, (1991).

[3] Luthans, F., Youssef, C. M., \&Avolio, B. J., Psychological capital: Developing the human competitive edge. USA : Oxford University Press, Inc., p. 102 (2007)

[4] Luthans, F., Youssef, C. M., \&Avolio, B. J., Psychological capital: Developing the human competitive edge. USA : Oxford University Press, Inc., p. 102 (2007)

[5] Bandura, A., Self-Efficacy, The Exercise of Control. W.H. Freeman and Company, New York, p. 3 (1997)

[6] Luthans, F., Youssef, C. M., \&Avolio, B. J., Psychological capital: Developing the human competitive edge. USA : Oxford University Press, Inc., p. 103. (2007)

[7] Luthans, F., Youssef, C. M., \&Avolio, B. J., Psychological capital: Developing the human competitive edge. USA : Oxford University Press, Inc., p. 103. (2007) 
[8] Luthans, F., Youssef, C. M., \&Avolio, B. J., Psychological capital: Developing the human competitive edge. USA : Oxford University Press, Inc., p. 103. (2007)

[9] Luthans, F., Youssef, C. M., \&Avolio, B. J., Psychological capital: Developing the human competitive edge. USA : Oxford University Press, Inc., p. 103. (2007)

[10] Luthans, F., Youssef, C. M., \&Avolio, B. J., Psychological capital: Developing the human competitive edge. USA : Oxford University Press, Inc., p. 104. (2007) 